\title{
Grundtvig-litteratur 1991-1996. En bibliografi
}

\author{
Ved Aage Jorgensen
}

Nedenstående bibliografi over Grundtvig-litteratur 1991-1996 viderefører tilsvarende bibliografier i Grundtvig-Studier 1968, 1971, 1974, 1979, 1984 og 1991 (kumuleret udgave - dækkende årene 1963-1985 - offentliggjort 1986).

Stoffet er ordnet efter bibliografiske kriterier frem for efter emnekredse. Tidsrummet gælder ikke absolut, idet enkelte bidrag af ældre dato og også enkelte fra begyndelsen af 1997 er medtaget. Arbejdet er afsluttet 5.6.1997.

Med hensyn til avisstoffet (artikler fortegnet ndf. u. VI, samt anmeldelser fortegnet i forbindelse med de arbejder, de omhandler) gælder, at bibliografien ikke gør krav på fuldstændighed. Medtaget er i alt væsentligt, hvad også Artikelbasen (den elektroniske videreførelse af Dansk artikelindeks og Dansk anmeldelsesindeks) har fundet det rimeligt at redde fra glemsel.

\section{Bibliographica}

Jørgensen, Aage, »Grundtvig-litteratur 1986-1990. En bibliografi«. Grundtvig-Studier, 1991, s. 137-61.

Possing, Birgitte \& Bruno Svindborg (red.), Det Kongelige Biblioteks Håndskriftafdeling. Erhvervelser 1924-1987. Vejledning $i$ benyttelse. I-II (med fortløbende paginering). 1995. S. 246-49. (Danish Humanist Texts and Studies, 12.)

\section{Udgaver}

Danske salmer - med noder og becifringer, kommentarer og digterbiografier. Udg. af Johannes Møllehave. Illustreret af Thormod Kidde. 1992. $392 \mathrm{s.}$ (»Mit liv med de danske salmer«, s. 9-26; »Hvad er en salme?«, s. 27-37; biografier over Sthen, Kingo, Brorson, Stub, Ewald, Grundtvig, Ingemann, Jakob Knudsen og K. L. Aastrup, s. 38-102.) (G s. 72-88.)

Selected Educational Writings. Udg. af Max Lawson. 1991. 110 s. (Indledning, »Profile: N. F. S. Grundtvig, 1783-1872«, s. 7-18.)

What Constitutes Authentic Christianity? Overs. af Ernest D. Nielsen. Philadelphia, 1985. 119 s. (Forord af EDN s. 11-14.) 


\section{Bøger}

Allchin, A. M., D. Jasper, J. H. Schjørring \& K. Stevenson (red.), Heritage and Prophecy. Grundtvig and the English-Speaking World. 1993. x, $330 \mathrm{~s}$. (Skrifter udg. af Grundtvig-Selskabet, 24.) (Indhold: A. M. Allchin, "Grundtvig and England. An Introduction «, s. 3-18; Anders Pontoppidan Thyssen \& A. M. Allchin, »Grundtvig's Relationship to England «, s. 19-32; Bent Noack, »Grundtvig and Anglo-Saxon Poetry«, s. 33-43; S. A. J. Bradley, "The First New-European Literature'. N. F. S. Grundtvig's Reception of Anglo-Saxon Literature«, s. 45-72; Jakob L. Balling, »Grundtvig, Dante, Milton, and the Problem of European Continuity«, s. 73-86; Flemming Lundgreen-Nielsen, »Grundtvig's Poetics«, s. 87-102; David Jasper, »N. F. S. Grundtvig, S. T. Coleridge. The Hymnwriter and the Poet «, s. 103-13; J. R. Watson, »Grundtvig and the English Hymn of the Romantic Period«, s. 115-32; Christian Thodberg, »The Importance of Baptism in Grundtvig's View of Christianity«, s. 133-52; Kenneth W. Stevenson, "Grundtvig's Hymns from an Anglican Point of View «, s. 153-70; Theodor Jørgensen, »Grundtvig's 'The Church's Retort' - in a Modern Perspective«, s. 171-90; Geoffrey Wainwright, »Reason and Religion. A Wesleyan Analogue to Grundtvig on Modernity and the Christian Tradition «, s. 191-214; Jens Holger Schjørring, »Church Continuity and the Challenge of Modernity. Grundtvig, the Oxford Movement, and Rationalist Theology«, s. 215-32; Lorenz Rerup, »N. F. S. Grundtvig's Position in Danish Nationalism«, s. 233-42; Vagn Wåhlin, "Denmark, Slesvig-Holstein and Grundtvig in the 19th Century«, s. 243-70; K. E. Bugge, »The School for Life. The Basic Ideas of Grundtvig's Educational Thinking «, s. 271-81; Hans Henningsen, »The Danish Folk High School«, s. 283-97; Holger Bernt Hansen, »Grundtvig and the Third World. The Transfer of Grundtvig's Ideas to Other Peoples and Cultures«, s. 299-322.) (Anm.: Peter Balslev-Clausen, Grundtvig-Studier, 1994, s. 264-67; Ove Korsgaard, Hфjskolebladet, 1994, s. 5356.)

Andersson, Henrik, Flemming Conrad, Per Dahl \& Jørgen Hunosøe, Udgivelse af danske litterare tekster efter 1800. En redegørelse for behov, problemer og perspektiver. 1996. S. 21-25. (Udg. af Det danske Sprog- og Litteraturselskab.)

Balslev-Clausen, Peter, Det vingede ord. Om N. F. S. Grundtvigs salmedigtning. 1991. 144 s. (Indledningsafsnittet, s. 7-11, afsnittene $» D r ø m$ og virkelighed « 1-2, s. 34-43 og 91-100, samt afsnittene om »Et Barn er født i Betlehem « og »I falmende blade, du kølige vind « indgår i afhandlingen Motiv og struktur. Studier $i$ N. F. S. Grundtvigs salmedigtning, bedømt for den 
teologiske Ph.D.-grad 1989.) (Tidligere offentliggjorte artikler: "Et Barn er født i Betlehem «, s. 20-33 < Hymnologiske Meddelelser, VIII, 1979; "Anmeldelser og salmesyn«, s. 44-50 < Hymnologiske Meddelelser, XII, 1983; »I falmende blade, du kølige vind«, s. 101-07 < Vartovbogen, 1981; »Hyggelig, rolig «, s. 66-71, »Trods længselens smerte«, s. 71-77, »Kom, Gud Faders Ånd fuldgod«, s. 77-84, »Rejs op dit hoved, al kristenhed «, s. 84-90, »Skyerne gråner og løvet falder «, s. 108-13, »Døden er den sidste fjende«, s. 113-19, »Herren han har besøgt sit folk«, s. 122-29, og »Herren taler: Øer, hører!« s. 136-42 < Organist-Bladet, 1983; »Æren er Guds i det høje den fortsatte julesang «, s. 130-35 < Church and Life, 1986.) (Anm.: Hans Hauge, Grundtvig-Studier, 1992, s. 129-34; Ove Paulsen, Hymnologiske Meddelelser, XXIV, 1995, s. 120-22.)

Bertelsen, Otto, Sфren Kierkegaard og de første grundtvigianere. 1996. 170 s. (Spec. s. 14-20, 36-40 og 158-61.)

Birkelund, Regner, Med Løgstrup til Grundtvig og Skolen for Livet. Om etik og astetik. 1994. iv, 111 s. (Skriftserie fra Danmarks Sygeplejerskehøjskole, 12.) (Om G spec. s. 57-76.)

Christensen, Martin Boje, N. F. S. Grundtvigs Irenceuspåvirkning set i sammenhoeng med to faser i forfatterskabet, 1820'erne og 1850'erne. 1992. iv, 50 s. (Universitetsopgave, 1990.)

Dahlén, Kerstin (red.), N. F. S. Grundtvig. Ett porträtt och en bibliografi. Grundtvigs aktualitet och inflytande $i$ våra dagar och inför framtiden. Göteborg, 1993. 30 s. (Indhold: Simon Grabowski, »N. F. S. Grundtvig, ett personligt porträtt«, s. 9-21; liste over G-litteratur i Nordens folkliga Akademi's bibliotek, s. 25-30.)

Dam, Poul, Grundtvig-tekster i sangbøgerne med sarligt henblik på højskolesangen. En bibliografisk oversigt. 1992. 184 s. (Anm.: Peter BalslevClausen, Hymnologiske Meddelelser, XXI, 1992, s. 234-35.)

Engberg, Poul, Grundtvig mellem фst og vest. Mellem Sofia og Ratio. 1993. 84 s. (Anm.: Hellmut Toftdahl, Grundtvig-Studier, 1994, s. 271-75.)

Engberg, Poul, Den gådefulde folkelighed. 1995. 99 s. (Om G passim.)

Jensen, Jørgen I., Den fjerne kirke. Mellem kultur og religiøsitet. 1995. 430 s., 8 pl. (Heri om »Paaske-Lilien« s. 382-99.) (Anm.: Nils Holger Petersen, Hymnologiske Meddelelser, XXIV, 1995, s. 227-33.) 
Grell, Helge, England og Grundtvig. Grundtvigs møde med England og dets betydning for hans forfatterskab. 1992. 182 s. (Anm.: A. M. Allchin, Grundtvig-Studier, 1993, s. 242-43; Jakob Holm, Dansk Kirketidende, CXLIV, 1992, s. 265-67.)

Grell, Helge, Grundtvig og Oxforderne. Grundtvigs møde med Oxfordbevagelsen og dens betydning for hans forfatterskab. 1995. 132 s. (Anm.: A. M. Allchin, Grundtvig-Studier, 1995, s. 278-80.)

Grundtvig undessa valossa. Artikkeleita teoksesta 'Grundtvig og grundtvigianismen i nyt lys', Århus 1983. Overs. af Anneli Koponen. 1989. $191 \mathrm{s.}$ (Bidrag af K. E. Bugge, Roar Skovmand, Christian Thodberg, Anders Pontoppidan Thyssen, Birgitte Thyssen og Sigurd Aa. Aarnes.)

Hansen, Niels Buur, Det guddommelige spejl. Fra N. F. S. Grundtvig til Gregory Bateson og Jacques Lacan. Et opgør med dualismens mareridt. 1993. 143 s. (Anm.: Hellmut Toftdahl, Grundtvig-Studier, 1993, s. 255-56.)

Kirken af levende Stene. Den grundtvigske tradition $i$ dansk kirkehistorieskrivning. 1994. 239 s. (Indhold bl.a.: Susanne Gregersen, "'Davidsnøglen til Krønikens Helligdom'. Den unge Grundtvigs kirkehistorieforståelse i verdenskrønikerne 1812, 1814 og 1817《, s. 23-44; Jakob Balling, »Bispestav, skolemesterpen - og menighed. Den ældre Grundtvig som kirkehistoriker«, s. 45-59.) (Anm.: Holger Jepsen, Højskolebladet, 1994, s. 547-48; William Michelsen, Grundtvig-Studier, 1995, s. 275-78.)

Klonteig, Olav, 'Menneskelivet er underligt'. Menneskesynet i grundtvigsk folkehøgskole og folkeopplysning. Oslo, 1992. $180 \mathrm{~s}$. Se reg. (Anm.: Olav Akerlie, Skjeberg Folkehøyskole. Årbok, 1991-92, s. 54-67.)

Korsgaard, Ove, Kampen om lyset. Dansk voksenoplysning gennem 500 år. 1997. 525 s. (Heri: »Grundtvigs oplysnings- og dannelsesidealer«, s. 171-90; cf. reg.)

Kvist, Vagn, Guds arinde går hver en storm. 1997. 115 s. (Salmelæsninger.)

Larsen, Steffen Hejlskov (red.), Denmāku bungakushi. Tokyo, 1993. S. 7280. (Japansk oversættelse af Knud Jensenius' litteraturhistorie, 6. udg., 1982.) 
Larsen, Torkild Mads, Mennesket er ingen abekat. Grundtvigs tanker om den folkelige højskole med specielt henblik på perioden 1832-71. 1993. 131 s. (Anm.: Kim Arne Pedersen, Grundtvig-Studier, 1994, s. 282-85.)

Meile, Eva, 'Plant en lilje'. Om Grundtvig og 3 af hans salmer. 1992. $48 \mathrm{~s}$.

Rode, Randi Habersaat, Barneglad og engleklog. Grundtvigs selvforståelse $i$ Sang-Vark til den danske Kirke, I. 1996. 182 s. (Skrifter udg. af GrundtvigSelskabet, 26.)

Röhrig, Paul, m.fl. (red.), Um des Menschen willen. Grundtvigs geistiges Erbe als Herausforderung für Erwachsenenbildung, Schule, Kirche und soziales Leben. Dokumentation des Grundtvig-Kongresses vom 7. bis 10. September 1988 an der Universität zu Köln. Weinheim, 1991. 336 s., 1 pl. (Indhold bl.a.: Paul Röhrig, "Einleitung«, s. 13-17; Erica Simon, »N. F. S. Grundtvig - ein Däne mit weltweiter Bedeutung «, s. 19-28; Poul Engberg, »Folkelighed - die nationalen, sozialen und demokratischen Komponenten in Grundtvigs Gedanken «, s. 29-37; Otto Dann, »Herder und die Anfänge der deutschen Nationalbewegung «, s. 38-52; Kaj Thaning, »Zuerst der Mensch... Grundzüge der Anthropologie Grundtvigs«, s. 55-64; Knud Eyvin Bugge, »Die pädagogischen Grundgedanken Grundtvigs im Lichte der neueren Forschung «, s. 67-73; Jens Grøn, »Hauptetappen in der Entwicklung der dänischen Volkshochschulen «, s. 75-81; Jakob Krøgholt, »Die Wirklichkeit der dänischen Volkshochschule. Organisationsform, gesetzliche Grundlagen, Bildungsziele, Lehrer «, s. 84-91; Arne Andresén, »Die Wirklichkeit der dänischen Volkshochschule. Teilnehmer, das Sekretariat der Volkshochschulen, kurze und lange Kurse«, s. 92-99; Hans Henningsen, »Identitätsprobleme der heutigen Volkshochschule zwischen Grundtvigs Idee und den Anforderungen der modernen Welt«, s. 101-05; Martha Friedenthal-Haase, "Grundtvig im Spiegel der deutschen Literatur zur Erwachsenenbildung um 1933«, s. 108-16; Norbert Vogel, »Die Anfänge der Grundtvig-Rezeption in der deutschen Volksbildung/Erwachsenenbildung «, s. 117-29; Hermann Scheile, "Grundtvig und die deutschen Heimvolkshochschulen«, s. 131-37; Paul Röhrig, "Eine schwierige Annäherung. Versuch, den Dialog zwischen dänischer und deutscher Erwachsenenbildung neu zu begründen «, s. 139-47; Knud Arnfred, »Leben und Erziehung in einem grundtvigianischen Haus«, s. 149-54; Eckhard Bodenstein, »Die ersten Alternativschulen. Idee und Aktualität der grundtvig-koldschen Freischulen «, s. 158-67; Jakob Andersen, »Eine Schule für das Leben im Geiste Grundtvigs. Die dänische Efterskole«, s. 169-76; Ebbe Kløvedal Reich, »Grundtvig, die Volkshochschule und die Emanzipation der Frau«, s. 180-83; Henrik Yde, »Die grundtvigsche Volkshochschule und die sozialistische Arbeiterbewegung «, s. 186-94; Inken 
Meinertz, "Die Volkshochschule und die Gewerkschaftsbewegung in Dänemark - aus der Sicht der Frauengewerkschaft«, s. 195-97; Erica Simon, »Grundtvigs 'Folkelighed' und Leopold Senghors 'Négritude' «, s. 200-03; Ok-Bun Lee, »Asiens Echo auf Grundtvigs Volksbildungsidee«, s. 206-09; Sri N. K. Mukherjee, "Grundtvigs Botschaft für das indische Volk«, s. 21015; Henning Schröer, "Grundtvigs theologisches und religionspädagogisches Erbe«, s. 219-25; Christian Thodberg, "Das lebendige Wort bei Grundtvig«, s. 226-32; Martin Greschat, "Kirche, Volk, Volkskirche in Deutschland 1918-1945«, s. 235-44; Theodor Jørgensen, »Volk und Volkskirche bei Schleiermacher und Grundtvig «, s. 246-57; Gerhard Strunk, »Tendenzen der kirchlichen Erwachsenenbildung in Deutschland«, s. 260-73; Günter Weitling, »Unterricht in Religion nach Grundtvig «, s. 274-85; Jürgen v. Heymann, "Grundtvigs Geist und Islands Freiheit. Rezeption, Wirkungen und Widerstände in Dänemarks ehemaliger Kolonie«, s. 291-305; Hans BekkerNielsen, »Für eine färöische Schriftsprache: N. F. S. Grundtvig, Svend Grundtvig und V. U. Hammershaimb«, s. 306-11; Jens Peter Ægidius, »Mythenerzählen in der Nachfolke Grundtvigs an den dänischen Volkshochschulen «, s. 312-19; Flemming Lundgreen-Nielsen, »Grundtvig als Dichter halb Aufklärer, halb Romantiker, ganz Christ«, s. 320-26.) (Anm.: Vilhelm Nielsen, Højskolebladet, 1992, s. 434-37; Vagn Wåhlin, Grundtvig-Studier, 1993, s. 256-69.)

Shimizu, Mitsuru \& Ove Korsgaard (red.), 'Forukehoisukōre' no sekai. Guruntovi to minshū no daigaku. Tokyo, 1993. 302 s. (Indhold bl.a.: Ove Korsgaard, »Guruntovi no 'forukērie, yunivāsaru' ", s. 241-51; Mitsuru Shimizu, »Folkehøjskole and Japan. How the Movement Was Introduced to Japan«, s. 291-78.) (2. opl., 1996.)

Thaning, Kaj, Hokuō no shisōka Guruntovi. Tokyo, 1987. 272 s. (På dansk 1972.)

Vogel, Ulrich, Bankede på ved paradis. [1993.] 144 s. (Skrifter udgivne af Grundtvig-Selskabet, 23.) (På omslaget: »N. F. S. Grundtvigs kriseoplevelser«.) (Anm.: Peter Balslev-Clausen, Grundtvig-Studier, 1994, s. 280-82.)

Yde, Henrik, Det grundtvigske i Martin Andersen Nexфs liv. 1991. 766 s. (i to bind). (Tysk resumé s. 732-55.) (Disputats forsvaret på Aarhus Universitet 4.10.1991; foromtale, Humaniora, V:1, 1991, s. 28-30; cf. »Bedømmelse af Henrik Ydes disputats «, Årsberetning 1991. Institut for Litteraturhistorie, Aarhus Universitet, 1992, s. 68-79; oppositionsindlæg: Anders Pontoppidan Thyssen, »Andersen Nexø og det grundtvigske «, Dansk Udsyn, LXXI, 1991, s. 197-215, og Anker Gemzøe, »En sammensat gigant.[..]«, Arbejderhistorie, 
nr. 39, 1992, s. 20-38.) (Anm.: Knud Bjarne Gjesing, Nordica, IX, 1992, s. 263-65; William Michelsen, Grundtvig-Studier, 1993, s. 244-52; Vilhelm Nielsen, Højskolebladet, 1992, s. 149-52; Henning Tjørnehøj, Information 25.7.1992.)

Zøllner, Lilian (red.), Almen dannelse - Folkelig dannelse - Folkelig livsoplysning. 1993. 152 s. (Indhold bl.a.: K. E. Bugge, »Grundtvigs syn på folkelig dannelse - dets muligheder før og nu«, s. 17-34 [hertil: Ove Korsgaard, »Den glemte dimension i den grundtvigske tradition «, s. 35-41; besvaret af KEB s. 42-45]; Hans Hauge, »Er lyset for de lærde blot. Om N. F. S. Grundtvig og Allan Bloom«, s. 73-94; Kjeld Fredens, »Fælleskultur og professionskultur «, s. 95-107 [hertil: Niels Buur Hansen, "Grundtvig og det æstetiske«, s. 108-13].) (Anm.: Vilhelm Nielsen, Højskolebladet, 1994, s. 56-59; Kim Arne Pedersen, Grundtvig-Studier, 1994, s. 275-79.)

Zøllner, Lilian, Grundtvigs skoletanker $i$ Japan, Filippinerne og Israel. 1994. 250 s. (Anm.: Vilhelm Nielsen, Højskolebladet, 1995, s. 105-07; Hellmut Toftdahl, Grundtvig-Studier, 1995, s. 281-83.)

Zøllner, Lilian, Grundtvig's Educational Ideas in Japan, the Philippines and Israel. Transl. by Anna Marie Andersen. 1994. 248 s.

Zøllner, Lilian \& Anna Marie Andersen (red.), Enlightenment in an International Perspective. 1995. 227 s. (Indhold bl.a.: Hans Henningsen, "Brief Outline of the Development of the Danish Folk High School with the Emphasis on Its Early History «, s. 7-18; A. M. Allchin, "We Know What We Love: Feeling and Thinking in Grundtvig's Understanding of Human Life«, s. 19-29; Morten Kvist, "Grundtvig as a Christian Thinker - or the Trinity of the Senses«, s. 30-43; Paul Röhrig, »The Origins and Development of the German Residential Folk High School as a Response to Grundtvig's Inspiration and to Political Challenges «, s. 130-46; Kenji Mitsumoto, »The Influence of N. F. S. Grundtvig on Dr. Shigeyoshi Matsumae«, s. 166-73; K. E. Bugge, "Some International Varieties of Grundtvig-Inspiration «, s. 185-95.) (Anm.: Karen Helene Havrehed, Grundtvig-Studier, 1995, s. 287-90.)

Zøllner, Lilian (red.), Rodfastet universalisme. N. F. S. Grundtvigs poesi, menneskesyn, kultursyn, skolesyn. 1996. $179 \mathrm{~s}$. 


\section{Dele af bøger}

Baggesen, Søren, Tematiseringer af teknik og udvikling $i$ dansk romantisk litteratur. 1993. 26 s. (Menneske \& Natur/Arbejdspapir, 34.) (Bl.a. om G.)

Bautz, Friedrich Wilhelm (udg.), Biographisch-bibliographisches Kirchenlexikon, II. Herzberg, 1990. Sp. 373-75.

Bhattacharya, Asoke, Empowering the Neoliterates. Relevance of Danish Folk High School and Co-operative Movements for Adult Education in India. Calcutta, 1994. iv, 150 s. (Spec. s. 59-106.)

Billeskov Jansen, F. J., »Grundtvig og Kierkegaard«. I hans: Grundtvig og Kierkegaard med ni andre åndshistoriske essays. 1996. S. 47-76. (< Kredsen, LX:2, 1994, s. 7-31.)

Birkelund, Regner, »Tag Grundtvig på ordet «. I: Tine Rask Eriksen, m.fl. (red.), Erfaringer. Et humanistisk og sundhedsvidenskabeligt perspektiv. 1996. S. 124-51.

Borum, Poul, Havfruens ansigt. Et essay og en serie digte. 1978. 38 s. (Om G s. 16-21.)

Borish, Steven M., The Land of the Living. The Danish Folk High Schools and Denmark's Non-Violent Path to Modernization. Nevada City, Calif., 1991. xxiv, 488 s. (Om G s. 15-20, 158-78 og 209-14; cf. reg.) (Anm.: A. M. Allchin, Grundtvig-Studier, 1992, s. 122-24; Vilhelm Nielsen, $H \phi j$ skolebladet, 1991, s. 553-57 [cf. VN, »Døden og næsten som højskolegrundlag?« smst., 1992, s. 6-9].)

Brouwer, Frans Johannes Cornelis, Vernieuwing in Drieklank. Een onderzoek naar de liturgische ontwikkelingen in Denemarken (c.1800 tot c.1950). Utrecht, 1990. 600 s. (Engelsk resumé s. 547-55.) (Om G passim, spec. s. 510-27.)

Bugge, K. E., »Grundtvigs syn på kristendomsundervisningen«. I: Religionspedagogisk forskning $i$ de nordiska länderna. Rapport från nordiska religionspedagogiska forskarkonferensen 12.-15.8.1984 i Åbo, Finland. Helsingfors, 1984. S. 225-34. 
Bugge, K. E., »Nicolai Frederik Severin Grundtvig«. I: Gestalten der Kirchengeschichte, IX/1: Die neueste Zeit, I. Stuttgart/Berlin/Köln/ Mainz, 1985. S. $200-17+1 \mathrm{pl}$.

Damsholt, Tine, Troen på folkeviljen. Analyse af en tradition i dansk demokratiopfattelse $i$ de sidste 200 år. 1994. S. 26-42 (»Kongehånd og folkestemme«). (Anm.: Vagn Wåhlin, Grundtvig-Studier, 1994, s. 290-93.)

Eichberg, Henning (red.), Schools for Life. 1992. 117 s. (Heri bl.a.: S. Rajathadri, »The Grundtvigian Vision of Man and Popular Identity - and its Relevance to Indian Context«, s. 29-36; Ove Korsgaard, »The Folkelig-Universal«, s. 83-92; Ejvind Larsen, »Sophia - The Mystic Dimension of Democracy«, s. 101-10.)

Elbek, Jørgen, »Tårers magt«. I hans: På sporet éfter enhjørningen. [1992.] S. 47-50. (< Information 30.3.1991; om G's »græske« vækkelse.)

Elbek, Jørgen, »Om hemmeligheder og himlen«. I: Niels Frank \& Janus Kodal (red.), Det forkladte hjerte. Festskrift til Poul Borum. 1994. S. 23-28.

Elbek, Jørgen, Fantasiens naturhistorie. Foredrag og artikler. 1995. 99 s. (Heri bl.a.: »Grundtvigs selvopgør«, s. 25-37 [< Dansk Udsyn, LXXII, 1993, s. 139- 52]; "Fantasiens naturhistorie«, s. 39- 58 [om H. E. Schack og G; < Fønix, XIV, 1990, s. 222-36]; »Grundtvigs ny muse«, s. 59-75 [< Dansk Udsyn, LXIX, 1989, s. 340-57].)

Engberg, Poul, Halvgudelivet i dødningesal. Traek af folkehфjskolens indre historie. 1988. 111 s. (»Grundtvigs idé om en folkelig højskole«, s. 9-12; »Grundtvig og de gudelige forsamlinger«, s. 30-39.)

Fibiger, Johannes \& Gerd Lütken, Litteraturens veje. Redaktion: Benedicte Kieler. 1996. S. 132-34.

Franklin, R. William \& Joseph M. Shaw, The Case for Christian Humanism. Grand Rapids, 1991. S. 155-61 (»The Church of Denmark: N. F. S. Grundtvig, 1839-1900«).

Griffith, Tony, »The Ugly Ducklings«. I hans: Scandinavia. 2. reviderede udg. Ken Town, 1993. S. 1-31, spec. s. 10-11. (1. udg., 1991.)

Hauge, Hans, »O, Mening. Om apostrofen hos N. F. S. Grundtvig, Jakob Knudsen og Henrik Nordbrandt«. I: Karin Gundersen \& Ståle Wikshåland 
(red.), EST IV: Kunst og mening. Grunnlagsproblemer i estetisk forskning. Oslo, 1992. S. 27-40. - Også i: Tania Ørum (red.), Til varks - dekonstruktion som lasemetode. 1994. S. 57-75. (Kulturteori og kulturhistorie, 4.) (Bogen, 106 s., har også bidrag af Jan Rosiek, Atle Kittang og Claus Bratt Østergaard, samt indledning af ТØ. [Anm.: Per Aage Brandt, Kritik, nr. 111, 1994, s. 62-66, med svar af CBØ, smst., nr. 112, 1994, s. 61-65; debat: PAaB, smst., nr. 113, 1994, s. 64-66, Niels Egebak s. 67, PAaB s. 68-70.])

Haugen, Einar, »'Modersmaal er vort hjertesprog'«. I: Oskar Bandle, m.fl. (red.), Nordische Romantik. Akten der XVII. Studienkonferenz der International Association for Scandinavian Studies 7.-12. August 1988 in Zürich und Basel. Basel/Frankfurt a.M., 1991. S. 108-13. (Beiträge zur nordischen Philologie, 19.)

Horsner, John Wedell \& Jørgen Michaelsen, På salmens tonestige. 50 salme-essays. 1993. 239 s. (< Dansk Kirkemusiker Tidende, juni 1984-april 1989.) (Bl.a. om 26 G-salmer.) (Anm.: Bjarne Ebert, Hymnologiske Meddelelser, XXIV, 1995, s. 122-25.)

Høirup, Henning, Så fjern og dog så nar. Erindringer. 1991. S. 155-65.

Jensen, Niels Lyhne, »Romantik i Grundtvigs 'Nordens Mytologi', 1808«. I: Oskar Bandle, m.fl. (red.), Nordische Romantik. Akten der XVII. Studienkonferenz der International Association for Scandinavian Studies 7.-12. August 1988 in Zürich und Basel. Basel/Frankfurt a.M., 1991. S. 205-13. (Beiträge zur nordischen Philologie, 19.)

Jensen, Søren, »Kierkegaard i den teologiske tradition. De danske forudsætninger for Søren Kierkegaards teologiske anskuelser «. I: Finn Frandsen \& Ole Morsing (red.), Denne slyngelagtige eftertid. Tekster om Søren Kierkegaard, I-III (med fortløbende paginering). 1995. S. 399-430, spec. s. 411-24. (Slagmarks Skyttegravsserie.)

Jørgensen, Theodor, „Grundtvigs økumeniske helligåndsteologi«. I: Henning Thomsen (red.), Du som går ud fra den levende Gud. Bibelteologiske og teologihistoriske overvejelser over helligånden. 1993. S. 70-84.

Jørgensen, Theodor, »Kontekstuel teologi - set i sammenhæng med Grundtvigs teologiske ansats «. I: S. Bergmann \& C. R. Bråkenhielm (red.), Kontextuell livstolkning. Teologi $i$ ett pluralistiskt Norden. Lund, 1994. S. 43-56. (Religio, 43.) 
Jørgensen, Theodor, »Guds sande menneske. Urbilledkristologi hos Schleiermacher og Grundtvig «. I: Lars Hartman, m.fl. (red.), Jesus-tolkningar idag. Tio teologer om kristologi. Stockholm, 1995. S. 206-34.

Jørgensen, Theodor, Korset $i$ Altet. 1995. 281 s. (Heri bl.a.: »Ondskab og forsoning. Schleiermachers og Grundtvigs frelsesforståelse«, s. 124-41 [< Text \& Kontext, 1986; på tysk]; "Guds sande menneske. Urbilledkristologi hos Schleiermacher og Grundtvig «, s. 142-64 [< Jesus-tolkningar idag. Tio teologer om kristologi. Stockholm, 1995. S. 206-34]; »Adskillelse og vekselvirkning. Om Grundtvigs syn på folkelighed og kristendom«, s. 165-76 [< Grundtvig-Studier, 1986, s. 71-83]; »Grundtvigs 'Kirkens Gienmæle' - læst i et nutidigt perspektiv«, s. 177-96 [< Grundtvig-Studier, 1992, s. 46-66].) (Anm.: Kim Arne Pedersen, Grundtvig-Studier, 1995, s. 283-87.)

Kjær, Jørgen, »Friedrich Nietzsche und Frederik Grundtvig. Ein Vergleich «. I: Gunnar Müller-Waldeck \& Michael Gratz (red.), Vernünfte und Mythen. Kolloquium der Universitäten Greifswald und Aarhus zum Thema: Aufklärung heute? (Mai 1992). Essen, 1996. S. 75-88. (Allgemeine Literatur- und Sprachwissenschaft, 6.)

Kofoed, Niels, Grundtraek af en europaisk poetik. Religion og astetik $i$ romantik og modernisme. 1994. 291 s. (Heri bl.a.: »Nogle hovedtyper i dansk romantik «, s. 109-94 [om G s. 111-34].)

Krarup, Søren, »Vækkeren og trøsteren«. I hans: Dansk kultur. 1993. S. 2746.

Kuhn, Hans, Defining a Nation in Song. Danish Patriotic Songs in Songbooks of the Period 1832-1870. 1990. S. 132-41 (om "Moders Navn er en himmelsk Lyd«), 141-52 (om »Langt høiere Bjerge«), 177-88 (om »Om Dannemarks Kvide der lød en Sang «), 230-31 (om »Kommer hid, I Piger smaa!«) og 254-55 (om »Det var en Sommer-Morgen«). Cf. reg.

Kuhn, Hans, „Grundtvigs Kulturrevolution«. I: András Masát (red.), Literature as Resistance and Counter-Culture. Papers of the 19th Study Conference of the International Association for Scandinavian Studies. Budapest, 1993. S. 290-94.

Kværndrup, Sigurd, »Grundtvigi pedagoogolised ideed«. I: Taani rahvaülikool täna. [u.å.] S. 19-24. (Udg. af Nr. Djurs Ungdomsskole for Demokratifonden. Estisk overs.: Matti Piirimaa. Også oversat til lettisk 1993 og litauisk 1994.) 
Larsen, Ejvind, »Af: Det levende ord. Om Grundtvig [1983]«. I: Asger S $\varnothing$ rensen, m.fl. (red.), Litteratur, VII: 1983-1987. 1988. S. 11-15.

Lundgreen-Nielsen, Flemming, »Dragedukke«. I: 80 ord til Christian Lisse 12. januar 1992. 1992. S. 32-33. (Om ordets særbetydninger hos G.)

Lundgreen-Nielsen, Flemming, »Grundtvig og danskhed«. I: Ole Feldbæk (red.), Dansk identitetshistorie. III: Folkets Danmark 1848-1940. 1992. S. 9187. (Cf. reg., IV, s. 573.)

Lundgreen-Nielsen, Flemming (red.), På sporet af dansk identitet. 1992. Se reg. s. 307.

Lundgreen-Nielsen, Flemming, »Kampen om Rom. Romerriget i dansk litteratur 1750-1900«. I: Otto Steen Due \& Jacob Isager (red.), Imperium Romanum. Realitet, idé, ideal. III. 1993. Spec. s. 259-73.

Lundgreen-Nielsen, Flemming, »Ulæselighedens charme«. I: Poul Behrendt, m.fl. (red.), Palmehaven. Institut for Nordisk Filologi. Levned og meninger. 1992. S. 87-96. (> Magasin fra Det kongelige Bibliotek, VII:3, 1992, s. 2737.)

Lundgreen-Nielsen, Flemming, »Grundtvigs københavnske aftenskole. Omkring den folkelige forening 'Danske Samfund' 1839-43«. I: Bente Scavenius (red.), Guldalderhistorier. 20 narbilleder af perioden 1800-1850. 1994. S. 100-09. (Også på engelsk og tysk.)

Lundgreen-Nielsen, Flemming, „Grundtvig's Norse Mythological Imagery. An Experiment that Failed«. I: Andrew Wawn (red.), Northern Antiquity. The Post-Medieval Reception of Edda and Saga. Enfield Lock, 1994. S. 4167.

Lyby, Thorkild C., »Grundtvigs tanker om præstefrihed - og grundtvigianernes«. I: Carsten Bach-Nielsen, m.fl. (red.), Ordet, kirken og kulturen. Afhandlinger om kristendomshistorie tilegnet Jakob Balling. 1993. S. 21435.

Lönnroth, Lars, »Fenrisulven på Vallekilde. Om folkhögskolans fornnordiska 'bragesnak' «. I hans: Skaldemjödet i berget. Essayer om fornisländsk ordkonst och dess återanvändning i nutiden. Stockholm, 1996. S. 146-68, 222. (Om G især s. 153-57.) 
Madsen, Arne Busk, Folket og de intellektuelle. 1993. 114 s. (Om G, Dostojevskij, Solsjenitsyn og Václav Havel.) (»Havel kontra Grundtvig «, s. 97102 < Tidehverv, LXVI, 1992, s. 142-44.) (Cf. Ove Korsgaard, »Havel kontra Grundtvig?«, Dansk Kirketidende, CXLV, 1993, s. 369-70.) (Anm.: Kim Arne Pedersen, Grundtvig-Studier, 1995, s. 301-02.)

Madsen, Arne Busk, »Grundtvig og U 90«. I: Majken Frost, m.fl. (red.), Frihed eller lighed. Et opgør med U 90. 1978. S. 56-65.

Malm, Mats, Minervas äpple. Om diktsyn, tolkning och bildspråk inom nordisk göticism. Stockholm, 1996. S. 130-32 og 133-35 (om »Nordens Mythologi«, hhv. 1808 og 1832), samt 231-33 (om G's vers, spec. i Saxo-oversættelsen).

Michelsen, Knud, »N. F. S. Grundtvig«. I: Ib Fischer Hansen, m.fl. (red.), Litteraturhåndbogen. I: Litteraturhistorisk oversigt; II: Forfatterbiografier / litteraturleksikon. 5. reviderede udg. 1996. II s. 49-52. (1. udg., 1981, i ét bd.; dér s. 372-76.)

Mortensen, Arne, »N. F. S. Grundtvig«. I: Espen Jerlang (red.), Selvforvaltning - padagogisk teori og praksis. 2. udg. 1991. S. 124-28. (1. udg., 1988; dér s. 111-15.)

Mortensen, Klaus P., Himmelstormerne. En linje $i$ dansk naturdigtning. 1993. S. 159-60. (Om »Vai nu, Dannebrog paa Vove!«)

Møllehave, Johannes, »Jævnt, muntert, virksomt « / „En salme man kan leve og d $\varnothing$ på«. I hans: Da alting blev anderledes. Udvalgte tekster 1958-96. Red. af Niels Birger Wamberg. 1997. S. 91-97 og 98-108. (< 1983; Kristeligt Dagblad 11.7.1994.)

Nielsen, Erik A., »Runen«. I: Henrik Blicher (red.), Som Runer paa Blad. Arbedspapirer om dansk litteraer romantik 1800-1820. Institut for nordisk Filologi, Kbhvn. 1996. S. 53-67 (spec. s. 59-65).

Nørager, Troels, Hjerte og psyke. Studier i den religiøse oplevens metapsykologi og diskurs. 1996. S. 245-49. (Om Villiam Grønbæks »Psykologiske tanker og teorier hos Grundtvig«, 1951.) (Disputats, forsvaret på Aarhus Universitet 15.11.1996.)

Pedersen, Jørgen, »Den dybe sammenhæng. Om Grundtvigs salme 'Hil dig, Frelser og Forsoner' som gengivelse af den cisterciensiske passionsrhytmus 
'Salve, mundi salutare' set på baggrund af hans forhold til den middelalderlige hymnedigtning «. I hans: Fra Augustin til Johs. V. Jensen. Essays og afhandlinger. 1991. S. 165-203. [< Hymnnologiske Meddelelser, XII, 1983, s. 194-239; ikke medtaget er det engelske resumé.]

Reich, Ebbe Kløvedal, »N. F. S. Grundtvig and 'Folkeligheden'«. I: Phan Nguyen (red.), International Conference on $\$$ Scandinavian Contributions to World Literature". Hanoi, 1993. S. 33-39. (Vietnamesisk udg.: Su dong gop cua bac au vao van hoc the gioi. Hanoi, 1993. 128 s.) (Cf. Henrik Yde, Holberg i Hanoi. Rapport om en konference 30. november-1. december 1993 på Hanois Universitet, Vietnam, om »Scandinavian Contributions to World Literature». 1994. 92 s.)

Roed, Susan, Pamves tra. Om krise, kunst og religiфsitet. 1988. S. 53-74 (»Vejen fra kaos til kosmos - tre eks.: Grundtvig, Kierkegaard og Blixen«), spec. s. 55-61.

Rossel, Sven H. (red.), A History of Danish Literature. Lincoln/London, 1992. S. 180-81 og 195-99. (A History of Scandinavian Literatures, 1.) (I afsnittet »From Romanticism to Realism«, skrevet af SHR; cf. reg. s. 678.)

Schjørring, Jens Holger (red.), National Identity and International Community. 1993. 140 s. (Indhold bl.a.: Lorenz Rerup, "Grundtvig and the 19th Century Nationalism«, s. 16-26; Ingrid Sokolova, »Grundtvig and Latvia«, s. 39-45; Inge Adriansen, "Danish and German National Symbols«, s. 61-90; Theodor Jørgensen, »Reflections on Grundtvig and Germany«, s. 91-104; Holger Bernt Hansen, »Grundtvig, Europe and the Third World. Dilemmas and Challenges «, s. 119-40.)

Schjørring, Jens Holger, »Om Fugl Fønix-motivet. Til belysning af forholdet mellem poesi og kirkelære«. I: Carsten Bach-Nielsen, m.fl. (red.), Ordet, kirken og kulturen. Afhandlinger om kristendomshistorie tilegnet Jakob Balling. 1993. S. 379-97. (Heri: »Fønix-motivet i Grundtvigs digtning«, s. 383-94.)

Stevenson, Kenneth, Handing On. Borderlands of Worship and Tradition. London, 1996. S. 83-99 og 139-41 (»Nikolai Grundtvig: Hymn-Writer Extraordinary«). Cf. reg.

Sørensen, Knud, »Om at være dansk«. I hans: Hvor bor kulturen? - og andre funderinger. 1994. S. 75-86. (Om G og Goldschmidt.) (> Højskolebladet, 1994, s. 609-13.) 
Thodberg, Christian, »N. F. S. Grundtvig «. I: Den Store Danske Encyklopaedi. VII: Fram-graesmåned. 1997. S. 599-602.

Thyssen, Peter, »Grundtvig og Guds Ord-teologien «. I: Peter Thyssen \& Anders Moe Rasmussen (red.), Teologi og modernitet. [Tilegnet H. C. Wind på 65-årsdagen 17. maj 1997.] 1997. S. 66-79.

Tjørnehøj, Henning, Louis Pio, folkevakkeren. 1992. 237 s. (Om G s. 2125.)

Uecker, Heiko \& Joachim Trinkwitz, Die Klassiker der skandinavischen Literatur. Die grossen Autoren vom 18. Jahrhundert bis zur Gegenwart. Düsseldorf, 1990. S. 90-95.

Vodskov, Hans, Litteraturkritik i udvalg. I: Litteraturkritiske artikler 18711886; II: Indledning / Kommentar / Bibliografi / Forkortelser / Titelregister / Personregister. Udg. af Erik Reitzel-Nielsen. 1992. xiv, 493; 256 s. (I: 107 større og mindre artikler/anmeldelser; om G s. 6-25, 119-29 o.fl.st.; II: indledning s. 11-60, kommentar s. 61-201, bibliografi s. 202-16.)

Wigh-Poulsen, Henrik, „'Guds Fred og God-Morgen'. 'Nyaarsmorgen' og traditionen «. I: Carsten Bach-Nielsen, m.fl. (red.), Ordet, kirken og kulturen. Afhandlinger om kristendomshistorie tilegnet Jakob Balling. 1993., S. 32237.

Yde, Henrik, »Gesandt for Grundtvig - Martin Andersen Nexø og Weimarrepublikkens højskolebevægelse«. I: Else-Marie Boyhus (red.), Midt $i$ h $\phi j-$ skolen. En antologi om det folkelige, det politiske, det universelle og det historisk-poetiske. 1991. S. 58-92.

Ægidius, Jens Peter, Christian Flor. Padagogen, politikeren, folkeoplyseren. 1994. 386 s. (Odense University Studies in History and Social Sciences, 178.) (Spec. henvises til afsnittet "Grundtvig-discipel«, s. 88-96; cf. reg. s. 378.) (Anm.: Kim Arne Pedersen, Grundtvig-Studier, 1995, s. 293-98 [s.m. tidligere JPÆ-bøger].)

Ægidius, Jens P., "Christen Flor og Grundtvig. Tre breve og et digt«. I: Flemming G. Andersen \& Lars Ole Sauerberg (red.), Traditions and Innovations. Papers Presented to Andreas Haarder. 1994. S. 383-95. (PEO/Prepublications of the English Department of Odense University, Special Issue.) [Brevene er fra CF til G.] 
Østergård, Uffe, »Grundtvig, grundtvigianismen og dansk national identitet metodiske problemer i studiet af Grundtvigs digtning «. I: Bernhard Glienke \& Edith Marold (red.), Arbeiten zur Skandinavistik. 10. Arbeitstagung der deutschsprachigen Skandinavistik 22.-27.9. 1991 am Weissenhäuser Strand. Frankfurt a.M. [o.a.st.], 1993. S. 387-407. (Texte und Untersuchungen zur Germanistik und Skandinavistik, 32.)

Østergård, Uffe, »N. F. S. Grundtvig, el grundtviguianismo y la identidad nacional danesa«. I: Claudio Bogantes (red.), Memorias del VI Congreso del Grupo de Trabajo de Estudios Regionales del CEISAL, Sandbjerg, Dinamarca, 15-19 de abril de 1993. América Latina - Europa Central - Dinamarca. 1994. S. 3-27. (Edición especial de Gacela [Gaceta de Estudios Latinoamericanos, Universidad de Aarhus].)

\section{Tidsskriftartikler}

Adriansen, Inge, »Danish and German National Symbols«. Grundtvig-Studier, 1993, s. 61-90.

Albeck, Gustav (medd.), »Et fragment fra Grundtvig-arkivet«. GrundtvigStudier, 1991, s. 23-32.

Allchin, A. M., "Påske i Konstantinopel. En englænders tanker, mens han skriver om Grundtvig«. Praesteforeningens Blad, LXXXI, 1991, s. 261-65.

Allchin, A. M., »N. F. S. Grundtvig and Nationalism in Wales«. GrundtvigStudier, 1992, s. 33-45.

Aronson, Harry, »Grundtvig och det grundtvigska arvet - litteraturöversikt«. Svensk teologisk kvartalskrift, LXVIII, 1992, s. 192-94.

Balling, Jakob, »Fra et 'konsultations'værelse i Chicago«. Grundtvig-Studier, 1996, s. 150-54. (Om International Ecumenical Consultation on N. F. S. Grundtvig. Chicago, July 19-23, 1995; cf. Hjelm, ndf.)

Balslev-Clausen, Peter, »Drøm og virkelighed. Grundtvigs forestilling om kristenlivets og salmesangens genfødsel«. Hymnologiske Meddelelser, XX, 1991, s. 65-114.

Balslev-Clausen, Peter, »Urolige Hjerte. Omkring Grundtvigs salme fra 1851«. Hymnologiske Meddelelser, XX, 1991, s. 134-95 og 203-64. (Indgår 
ligesom ovennævnte artikel som del af lic.theol.-afhandlingen »Motiv og struktur. Studier i N. F. S. Grundtvigs salmedigtning«, bedømt 1989.)

Balslev-Clausen, Peter, »Hvad er det, de synger?« Vartovbogen, 1991, s. 1528. (Om skolesangbøger.)

Billeskov Jansen, F. J., »Grundtvig og Kierkegaard«. Kredsen, LX:2, 1994, s. 7-31.

Birkholm, Klavs, »Jord og Himmel at forbinde«. Vartovbogen, 1994, s. 7683. (Anm. af årbogen: William Michelsen, Grundtvig-Studier, 1995, s. 30306.)

Boas, Hans Henrik Midtgaard, »Sammenhængen mellem Skaberånd og Helligånd i Grundtvigs teologi«. Grundtvig-Studier, 1993, s. 159-90.

Bradley, S. A. J., "Grundtvig's Palm Sunday 1867 and the Anglo-Saxon 'Descent into Hell'«. Grundtvig-Studier, 1993, s. 198-213.

Bradley, S. A. J., „'Stridige Stykker snild jeg forbandt'. Grundtvig's Creative Synthesis of Anglo-Saxon Sources«. Grundtvig-Studier, 1996, s. 97-127.

Brandt, Per Aage, "Velkommen i hytten!«. Litteraturmagasinet Standart, VI:5, 1992, s. 20. (Om »Velkommen igjen, Guds Engle smaa«.)

Brandt-Nielsen, E., »Grundtvig og det kvindelige«. Dansk Udsyn, LXXII, 1993, s. 161-68.

Brandt-Nielsen, Einar, „Guldæbler i sølvskåle. Lidt om Grundtvigs humor og folkelige billeder i 'Sangværket' og andre steder « / »Kun ved badet og ved bordet. Lidt om Grundtvigs nadversyn« / »Eva og Maria. Glimt fra Grundtvigs 'Sangværk'« / »Det kirkelige dilemma«. Dansk Kirketidende, CXLV, 1993, s. 131-36, 211-15, 256-60 og 326-31.

Brandt-Nielsen, E., »Kvinderne i Grundtvigs salmer«. Dansk Kirketidende, CXLVI, 1994, s. 140-43.

Brisson, Benedikte, »En underlig krig? En salme og dens danske gendigtninger sat i perspektiv«. Prasteforeningens Blad, LXXXVII, 1997, s. 32226, spec. s. 324-25. (Om »I dødens bånd vor frelser lå«.) 
Brun, Jens, »Da Grundtvig blev grundtvigsk «. Dansk Kirketidende, CXLVIII, 1996, s. 336-38 og 352-54.

Carlsen, Jørgen, »Den liflige klingen«. Højskolebladet, 1994, s. 391-93; Dansk Ungdom og Idrat, 1994, nr. 25, s. 14-15.

Carlsen, Jørgen, »Den grænseløse Grundtvig«. Højskolebladet, 1996, s. 38082.

Christensen, Bent, »Fra 'Fra drøm til program' til program«. Dansk Kirketidende, 147, 1995, s. 103-06 og 120-23.

Christensen, Frede Dyrby, »Noe om norsk folkehøgskole - og om Grundtvig«. Skjeberg Folkehøgskole. Årbok 1969-86, 1986, s. 11-17.

Christiansen, Erling, »Grundtvig-overvejelser«. Grundtvigs Højskole Frederiksborg, 1983, s. 27-34.

Dahl, Per, »Troens Nefa-lygte«. Litteraturmagasinet Standart, VI:5, 1992, s. 21. (Om »Dejlig er den Himmel blaa .)

Dam, Poul, »En skillestreg«. Hymnologiske Meddelelser, XXIV, 1995, s. 134-35. (Om »Velkommen igen, Guds engle små«.)

Damsholt, Tine, »'Jeg er en gammel Royalist, det ved De nok'. Elementer i Grundtvigs politiske tænkning«. Grundtvig-Studier, 1995, s. 140-62.

Ditlevsen, Kirsten, „Maria - et forbillede for kristne? Grundtvigs syn på Jomfru Maria«. Grundtvig-Studier, 1991, s. 112-33.

Ditlevsen, Kirsten, »Grundtvig og jomfru Maria«. Vartovbogen, 1991, s. 2947.

Eisenberg, Christian, »Ein unbeachteter Artikel N. F. S. Grundtvigs aus dem Jahre 1837. 'Om det Ny Testamente i Grundsproget eller Om Alcala-Texten og Bibelkritiken' «. Grundtvig-Studier, 1993, s. 214-36.

Elbek, Jørgen, »Grundtvigs selvopgør«. Dansk Udsyn, LXXII, 1993, s. 13952.

Elbek, Jørgen, »Som sole - min rose«. Litteraturmagasinet Standart, VI:5, 1992, s. 22. (Om »Velkommen igjen, Guds Engle smaa«.) 
Ertner, Jørgen, »Grundtvigs adventsnat og julemorgen«. Roskilde Stiftsblad, XLVI, 1995, s. 179-88.

Franklin, R. William, »Johann Adam Möhler and N. F. S. Grundtvig. The Bridge of Romanticism«. Grundtvig-Studier, 1996, s. 128-45. (Cf. William Michelsen, »Om Grundtvig, J. A. Möhler og romantikken«, smst. s. 146-49.)

Furre, Berge, »Grundtvig på gjesting i Noreg«. Kirke og Kultur, LXXXXVIII, 1993, s. 291-305.

Glenthøj, Elisabeth Albinus, »Grundtvigs teologiske udvikling til omkring affattelsen af 'De Levendes Land'. Om den eskatologiske spænding i forståelsen af Guds rige«. Grundtvig-Studier, 1995, s. 217-74.

Gleerup, Jørgen, »Arven fra Grundtvig i systemteoretisk perspektiv«. $H \varnothing j$ skolebladet, 1994, s. 102-06.

Grane, Leif, »Den gammelgrundtvigske periode. Teologisk kritik og polemik i 1850'erne og 1860'erne«. Fønix, II, 1977-78, s. 92-109, spec. s. 98-101 (om »Kirkefejden «).

Grell, Helge, "'Langt mere eventyrligt end historisk'. Om Grundtvigs forhold til England «. Grundtvig-Studier, 1993, s. 145-58.

Græsholt, Thorkild, »I Grundtvig-året - en salmehistorisk iagttagelse «. Stiftsbog og landemode-akt for Lolland-Falsters stift, 1983, s. 46-48. (Om "Har Haand du lagt paa Herrens Plov«, 3. strofe.) (Optrykt i: Hymnologiske Meddelelser, XIII, 1984, s. 166-68. [Hertil replik af Børge Møller-Madsen, smst., s. 225-26.])

Hamre, Bjørn, »Højskoledrømme mellem Grundtvig og den bangalske virkelighed«. Vartovbogen, 1994, s. 33-44.

Hansen, Holger Bernt, »Grundtvig, Europe and The Third World: Dilemmas and Challenges«. Grundtvig-Studier, 1993, s. 119-40.

Hartung, Sten, „Var Grundtvig højkirkelig?« Dansk Kirketidende, CIL, 1997, s. 118-20.

Haslam, Gerald M. (udg.), »Prædiken. Dom. 9 Trinit [05 Aug] Ev Luc. 16. 1-10 / Exordium Es. 44.21: Ørsl[öf] 1792, visit. Dna Præpos: Faber... Et utrykt manuskript af Johan Grundtvig«. Grundtvig-Studier, 1996, s. 33-44. 
Hauge, Hans, „Grundtivig gråner. 'Så gråne da kun, I gule hår' «. Årbog for Københavns Stift, 1996, s. 50-56.

Heggem, Synnøve, "En Grundtvigstrofe - om hellig og alminnelig kjærlighet«. Kirke og kultur, 100, 1995, s. 31-44. (Om »Christi Kirke! lydt du kvæde«, strofe 1.)

Henningsen, Hans, »Om fænomenet 'det folkelige' «. I: Søren Jensen (red.), Omkredsen. Studenterkredsen i Århus 1942-1992. 1992. S. 21-32, spec. s. $24 \mathrm{ff}$.

Henningsen, Hans, »Universalitet og univers hos K. E. Løgstrup - og Grundtvig«. Højskolebladet, 1993, s. 553-58. (Debat: Ole Vind, smst., s. 601-04; HH, smst., s. 622-23; OV, smst., 1994, s. 8-9; Tyge Arnfred, smst., s. 107.)

Henningsen, Hans, »Synet på natur og historie hos Grundtvig og Løgstrup«. Grundtvig-Studier, 1994, s. 92-106.

Henningsen, Hans, »Højskole i 150 år - bøger omkring et jubilæum«. Grundtvig-Studier, 1995, s. 193-204.

Henriksen, Jens Ole, »Gud, Grundtvig og det danske folk«. Vartovbogen, 1991, s. 7-14.

Himmelstrup, Per, »Nikolaj F. S. Grundtvig und seine Erben. Heimvolkshochschulen in Dänemark «. Die österreichische Volkshochschule, Heft 130, 1983, s. 77-82.

Hjelm, Norman A., »International Ecumenical Consultation on N. F. S. Grundtvig. Chicago, July 19-23, 1995«. Grundtvig-Studier, 1996, s. 155-57.

Holm, Jette, »Sov sødt, barnlille!«. Dansk Kirketidende, CXLVI, 1994, s. 195-97.

Holm, Jette (udg.), »Grundtvigs prædiken 2. s.e.trin. 1840«. GrundtvigStudier, 1996, s. 25-32.

Holmberg, Anders, »Grundtvig som kontextuell teolog «. Grundtvig-Studier, 1996, s. $165-89$.

Holt, Else Kragelund, »'Stat op i Gry, min Gud!' Tre gammeltestamentlige salmer, gendigtet af Grundtvig «. Grundtvig-Studier, 1996, s. 77-96. (Om SV 
206 »I de gyldne Himmel-Sale«, 207 », Gud, min Gud og Fader« og 209 »Stat op i Gry, min Gud, stat op«.)

Højskolebladet, 1992, s. 575-89: temasektion om Grundtvigs digt »Folkeligheden«. (Omfatter: Flemming Lundgreen-Nielsen, "Baggrund og tekstforhold«, s. 578-82; Poul Dam, »Digtet i sangbøgerne«, s. 582-84; Jens Bonderup, »Folkeligt skulle alt nu have været...«, s. 584-86; Ulla Viskum, »Et godt ægteskab«, s. 586-89.)

Høystad, Ole M., »Grundtvig og Mikaelshola«. Årbok for Telemark, XXXVI, 1990, s. 97-109. (Bl.a. om »Nyaars-Morgen«.)

Iversen, Hans Raun, »Becoming a Christian in a Non-Christian Age. An Attempt to Answer an Old Question from a Modern Grundtvigian Standpoint«. Studia Theologica, XXXXVI, 1992, s. 133-46.

Jacobsen, Anders-Christian, »Skabelse og fuldendelse hos Irenæus - med et udblik til Grundtvig«. Prasteforeningens Blad, LXXXVI, 1996, s. 429-38. (Om G s. 435-38.)

Jasper, David, »N. F. S. Grundtvig, S. T. Coleridge - the Hymnwriter and the Poet«. Grundtvig-Studier, 1991, s. 56-67.

Jensen, Henrik Gade, »Operation Gyldenår«. Højskolebladet, 1993, s. 12325 .

Jensen, Henrik Gade, »Grundtvigs statsopfattelse«. Dansk Udsyn, LXXIII, 1994, s. 85-97.

Jensen, Ole, »'Grundtvig Light'. Skal højskolen forkynde kristendom?« Grundtvigs Højskole Frederiksborg, 1995, s. 45-48. (> Højskolebladet, 1996, s. 21-23; cf. Ole Hjorth, »Forpligtet på et teologisk grundlag?«, s. 23-25.)

Jørgensen, Keld Gall, »Eftirlikingar og pýðingar. Áhrif og afdrif Íslendingasagna í Danmörku«. Skirnir, CLXVII, 1993, s. 149-75. (Om G s. 155-58.)

Jørgensen, Theodor, „Grundtvigs 'Kirkens Gienmæle' - læst i et nutidigt perspektiv«. Grundtvig-Studier, 1992, s. 46-66. (> hans: Kirken i Altet, cf. ovf.)

Jørgensen, Theodor, »Reflections on Grundtvig and Germany«. GrundtvigStudier, 1993, s. 91-104. 
Jørgensen, Aage, »Romantikkens Holberg-reception - en linje fra N. F. S. Grundtvig til N. M. Petersen«. Dansk Kirketidende, CIL, 1997. (I trykken.)

Kanmai, Toshitaka, »N. F. S. Guruntovi no kyōikuron. 'Hokuō shinwa' no 'joron' kara«. Tōkai daigaku kōchū kiyō, XXX, 1994, s. 243-57. [G's uddannelsesteorier. Fra indledningen til »Nordens Mytologi «.]

Kildegaard, Axel C., »Grundtvig's Legacy Through the American Evangelical Lutheran Church«. Church and Life (Askov, Minn.), XLI:7, 1992, s. 3-6.*

Krarup, Søren, »Da bløder mit hjerte i mig«. Tidehverv, LXVII, 1993, s. 105-07. (G’s syn på statsborgerskab, - og det nuværende Folketings.)

Kvist, Morten, "Grundtvigs kirkelige anskuelse og Martensens sofa«. Dansk Kirkeliv 1992-1993, 1992, s. 12-21. (Om Vilhelm Birkedals konflikt med konge og regering 1864-65.)

Larsen, Ejvind, »Grundtvig i dag«. Grundtvigs Højskole Frederiksborg, 1983, s. 21-29.

Larsen, Øjvind, »Grundtvig og den demokratiske kultur i Danmark «. Social kritik, nr. 34, 1994, s. 46-53.

Lawson, Max, »Nikolay Grundtvig (1783-1872)«. Prospects. Quarterly Review of Education, XXIII [nr. 87-88: Thinkers of Education, 2], 1994, s. 613-23.

Leilund, Helle, "Grundtvig i dansk identitetshistorie«. Nord Nytt, nr. 54, 1994, s. 5-13.

Litvack, Leon B., »The Greek Hymn Translations and Adaptations of N. F. S. Grundtvig and J[ohn] M[ason] Neale«. The Hymn Society of Great Britain and Ireland, XII:10, 1990, s. 182-87.

Lundgreen-Nielsen, Flemming (medd.), "Grundtvig om danskhed og modersmål i 1839. En tale 5. november 1839«. Grundtvig-Studier, 1992, s. 7 19.

Lundgreen-Nielsen, Flemming, "Sjæleøje-Stavnen eller Sjæle-Færge-Stavnen? En tekstkritisk drøftelse «. Grundtvig-Studier, 1994, s. 108-21. (Om »Gammel nok jeg nu er blevet«, aftrykt s. 107.) 
Lundgreen-Nielsen, Flemming, »Grundtvigs nordisk-mytologiske billedsprog - et mislykket eksperiment?« Grundtvig-Studier, 1994, s. 142-98. (Cf. Jens Peter Ægidius, »Grundtvig og myterne - en replik til Flemming LundgreenNielsen«, smst., 1996, s. 158-64.)

Lundgreen-Nielsen, Flemming, »Grundtvig og guldalderens København«. Grundtvig-Studier, 1995, s. 107-39.

Lyster, Jens, »Tre forsynssalmer. DDS 490, 496 og 511 «. Kritisk forum for praktisk teologi, nr. 67, 1997, s. 48-59, spec. s. 53-59. (511 af G, 496 omarbejdet af G.)

Meincke, Inga, »Schiffbruch \& Erlösung. Ein Schattenriss«. Grundtvig-Studier, 1996, s. 190-206.

Michelsen, William, »Vejen fra tvang til frihed i Grundtvigs liv og forfatterskab«. Grundtvig-Studier, 1991, s. 33-55. (Cf. hertil Kaj Thaning, »Replik«, smst., 1992, s. 93-96.

Michelsen, William, »Om Grundtvigdebatten med svar til mine kritikere«. Grundtvig-Studier, 1992, s. 97-105.

Michelsen, William, „Gustav Albeck 1906-1995«. Grundtvig-Studier, 1995, s. 11-16.

Michelsen, William, »Om tankebilledet i Grundtvigs sidste digt«. GrundtvigStudier, 1995, s. 102-06.

Michelsen, William, [Anmeldelse af »Vartovbogen, 1995«.] Grundtvig-Studier, 1996, s. 207-11. (Især om folkehøjskole-grundtvigianisme 1844-1994.)

Mikkelsen, Inger Lise, »Hyrdeliv og paradisdrøm. Om Grundtvigs syn på hyrder«. Grundtvig-Studier, 1994, s. 122-41.

Nedergaard, Niels Jørgen, „Grundtvig og Vagn Christensen«. Månedsskrift for praktisk lagegerning, LXIX, 1991, s. 475-82.

Nielsen, Jakob Fløe, »Grundtvigs helligåndssalmer og kirkesynet«. Dansk Kirketidende, CXLVIII, 1996, s. 52-56 og 68-72.

Nielsen, Jakob Fløe, „Grundtvigs syn på sprog«. Den frie Larerskole, XXXVIII:1, 1990, s. 16-17. 
Nielsen, Vilhelm, »Grundtvig på Skamlingsbanken [1844]«. Højskolebladet, 1994, s. 330-33.

Nielsen, Åge, "Grundtvig i sange og salmer«. Dansk sang, XLII, 1990-91, nr. 3, s. 29 og 32 , nr. 4 , s. $30-31$, nr. 5, s. 24 og 26-27, nr. 6, s. $28-29$ og 32; XLIII, 1991-92, nr. 5, s. 13-14, nr. 6, s. 15-17.

Noack, Bent, »Grundtvigs sidste digt«. Vartovbogen, 1993, s. 102-12. (Om »Gammel nok jeg nu er blevet«.) (Anm.: William Michelsen, Grundtvig-Studier, 1994, s. 268-70.)

Nägele, Horst, »N. F. S. Grundtvigs Abwendung von der deutschen idealistischen Philosophie. Dänischnationale und universale Perspektiven - auch mit Blick auf den geplanten europäischen Binnenmarkt«. Neue Deutsche Hefte, XXXVI:3 [nr. 203], 1989, s. 453-58.

Nägele, Horst, »Warum wir uns mit N. F. S. Grundtvigs idealismus-kritischen Abhandlungen beschäftigen. Beobachtungen mit Blick auf ein umfassenderes Forschungsprogekt zu N. F. S. Grundtvig (1783-1872)«. GrundtvigStudier, 1995, s. 205-16.

Olsen, Lone, „Grundtvigs levende ord og Habermas' kommunikative handlingsmodel«. Efterskolen, XXIV:7, 1991-92, s. 171-74.

Ottesen, Doris, "'Tro er et Hjerte-Anliggende' «. Årbog for Kфbenhavns Stift, 1994, s. 20-26.

Ozumba, Kachi E., »Grundtvigske rødder i Nigeria«. Vartovbogen, 1991, s. 109-17.

Pedersen, Kim Arne, »Om at læse 'Danne-Virke'. Nogle hermeneutiske overvejelser«. Grundtvig-Studier, 1991, s. 96-111.

Pedersen, Kim Arne, "Grundtvig og teologien i dag. Grundtvig og moderne teologi set i lyset af Kants tænkning«. Dansk teologisk Tidsskrift, LIV, 1991, s. $183-208$.

Pedersen, Kim Arne, »Treenighed og gudbilledlighed«. Grundtvig-Studier, 1992, s. 106-15.

Pedersen, Kim Arne (medd.), "Om Troen og dens Indflydelse paa Jordlivet eller Om Kirke og Stat«. Grundtvig-Studier, 1995, s. 26-74. 
Pedersen, Kim Arne, »Metafysik og Åbenbaring. Om de triadiske, respektive trinitariske strukturer i N. F. S. Grundtvigs tænkning 1812-1815«. Grundtvig-Studier, 1995, s. 75-101.

Pedersen, Kim Arne, »Grundtvig og Geijer - to møder og en afsked. En redegørelse for forbindelserne mellem Erik Gustav Geijer og N. F. S. Grundtvig, indeholdende en transskription af Fascikel 379.24 og Fascikel 379.80 med Grundtvigs to udkast til en tale til Geijer i 1846«. Grundtvig-Studier, 1996, s. 45-57.

Pedersen, Kim Arne, "Center for Grundtvig-studier - en præsentation «. Dansk Kirketidende, CXLVIII, 1996, s. 256-60 og 275-77.

Pedersen, Kim Arne, »Hovedlinjer i Grundtvig-forskningen siden 2. Verdenskrig «. Dansk Kirketidende, CXLIII, 1996, s. 278-80, 292-94, 338-42 og 354-60.

Petersen, Anne Kjestine, »Grundtvig - Kieslowski og højskolen«. Vartovbogen, 1995, s. 15-22.

Poulsen, Gunnar J., »Om nationalisme og folkelighed. Med Grundtvig som rådgiver«. Vartovbogen, 1991, s. 151-58.

Reich, Ebbe Kløvedal, »Forjættelsen om hjertets vovemod«. Stiftsbog og landemode-akt for Lolland-Falsters stift, 1983, s. 20-32.

Rerup, Lorenz, "Grundtvigs indflydelse på den tidlige danske nationalisme«. Grundtvig-Studier, 1992, s. 20-32.

Rerup, Lorenz, "Grundtvig and 19th Century Nationalism«. Grundtvig-Studier, 1993, s. 16-26.

Riis, Knud, »Ak! hvorlænge var Adam i Paradis?« Højskolebladet, 1993, s. 441-44. (Om »Gud planted en Have«.)

Riis, Knud, »Højskolen - et luthersk kloster? Skitse til en justering af det grundtvigske«. Dansk Kirkeliv 1993-1994, 1993, s. 22-63, spec. 45-60 (»Om Grundtvig. To punktstudier«). (Cf. Vilhelm Nielsen, „Grundtvig som postmodernist?«, Højskolebladet, 1994, s. 313-15.)

Schröder, Stephan Michael, »Der unbequeme Däne« / »Der missverstandene Däne«. Nordeuropa-Forum, 1992, nr. 2, s. 42-45, og nr. 3, s. 44-46. 
Sokolova, Ingrid, »Grundtvig and Latvia«. Grundtvig-Studier, 1993, s. 3945.

»Sprechen wir über Grundtvig!« Erwachsenenbildung in Österreich, Heft 3, 1983, s. 18-20. (Samtale mellem Hannelore Blaschek, Reinhold Ritt og Martin Wiedemair.)

Sørensen, Mogens, »Døden i Grundtvigs salmedigtning«. Nemalah, XII, 1993, s. 71-82.

Thaning, Kaj, »To årstal. Replik« Grundtvig-Studier, 1991, s. 134-36.

Thodberg, Christian, „Grundtvigs græske vækkelse og Sangværket«. Dansk Kirkesangs årsskrift 1989-1993, 1993, s. 10-33.

Thomsen, Erling Stougaard, »Folke-kristendom«. Ribe Stiftsbog, 1994, s. 3343. (Om G og Dostojevskij.)

Thunberg, Lars, »Grundtvig og de latinske salmer - et teologisk perspektiv «. Grundtvig-Studier, 1992, s. 67-92.

Thyssen, Anders Pontoppidan, »Grundtvigianismen og J. C. Christensens folkekirke«. Dansk Kirketidende, CXLV, 1993, s. 340-43 og 362-67.

Thyssen, Peter, »Grundtvig, Laub og kirkesangen«. Grundtvig-Studier, 1991, s. 229-55.

Thyssen, Peter, »Kender du de gamle salmer? Salmefornyelse i et grundtvigsk perspektiv«. Kritisk forum for praktisk teologi, nr. 60, 1995, s. 44-56.

Thøgersen, Stig. »Grundtvig i Kina«. Grundtvig-Studier, 1995, s. 163-92.

Vind, Ole, »Herder og højskolen«. Højskolebladet, 1995, s. 201-05.

Vogel, Ulrich P. G., »Det sakramentale som vishedsgrund og livshjælp«. $F \phi$ nix, nr. 17, 1993, s. 25-45. (Især om G.)

Warming, Per, »'Svar ej fattes skoven' - en grundtvigsk folkevise«. $H \phi j$ skolebladet, 1994, s. 85-91. (Om »Folkeligt skal alt nu være«.)

Wigh-Poulsen, Henrik, »Digteren og Den Sandheds Ånd. Grundtvigs helligåndsteologi og den engelske romantik«. Grundtvig-Studier, 1991, s. 68-85. 
Wigh-Poulsen, Henrik, »Barnet i haven - analyse af et Grundtvigsk motiv og dets rødder i en tidlig litterær tradition«. Grundtvig-Studier, 1996, s. 58-76. (Om »Til Sibbern« og »Udby Have«.)

Wåhlin, Vagn (medd.), »Politiske Betragtninger med Blik paa Danmark og Holsten « / »Grundtvig i politik op til 1830«. Grundtvig-Studier, 1994, s. 1758 og 59-91.

Yahil, Leni, "National Pride and Defeat. A Comparison of Danish and German Nationalism «. Journal of Contemporary History, XXVI, 1991, s. 45378 , spec. s. $454-55$ og 458-67.

Zøllner, Lilian, »Grundtvigs skoletanker i Filippinerne«. Grundtvig-Studier, 1994, s. 199-28.

Zøllner, Lilian, "Grundtvigs skoletanker i Argentina«. Nornesalen. Forskning 1995. [1996.] S. 25-32.

Øhrstrøm, Peter, »Grundtvig og internettet«. Vartovbogen, 1995, s. 39-52. (Også i: Jyllands-Posten 19.5.1995.)

Ørtved, Arne, »Det levende ord«. Kvan, nr. 31, 1991, s. 7-18.

Aarnes, Sigurd Aa., "Grundtvig og Norge - noen hovedlinjer«. GrundtvigStudier, 1993, s. 191-97.

Aasen, Kirsti, »'Helt kun i mand og kvinde'. Grundtvigs tanker om den fruktbare dobbelthet«. Grundtvig-Studier, 1991, s. 86-95; Kirke og Kultur, LXXXXVI, 1991, s. 361-69.

\section{Avisartikler}

Abildgaard, Inger, »Jorden rundt med Grundtvig«. Kristeligt Dagblad 22.8. 1991. (Om voksende højskoleinteresse.)

Abildgaard, Inger, »Skibet er ladet med Grundtvig«. Kristeligt Dagblad 13.4.1991. (Om østeuropæisk G-interesse.)

Aidt, Mik, »Grundtvig i troperne«. Politiken 5.11.1994. (Om G-seminar i Ghana.) 
Andersen, Christian, »Julens sorg og julens glæde«. Kristeligt Dagblad 28.12.1992.

Andersen, Christian, »Grundtvigs pinsesalmer«. Kristeligt Dagblad 29.5. 1993.

Appel, Jacob, »Vartov og Grundtvig«. Berlingske Tidende 25.4.1995.

Billeskov Jansen, F. J., »Åndsfrihed - Grundtvig og Kierkegaard«. Kristeligt Dagblad 30.8.1995.

Bjørn, Claus, »Grundtvig og [Thomas Thaarups] 'Høstgildet' «. Kristeligt Dagblad 10.3.1994.

Brandt-Nielsen, E., »Kære Frederik«. Jyllands-Posten 31.7.1993. (Brev til G fra »en fortrolig ven, bordfælle og embedsbroder«.)

Bækdorf, Elna, »Den kontroversielle Ingemann«. Kristeligt Dagblad 28.5. 1996. (Debat med G om »kødets opstandelse«.)

Christensen, Knud Simon, »Grundtvigs bibliotek ligger i Vartov«. Kristeligt Dagblad 5.10.1992.

Dahlgreen, Lillian Munk, »Julesorgens laterna magica«. Kristeligt Dagblad 13.12.1994. (Refleksion over »Velkommen igjen, Guds Engle smaa«, slutstrofen.)

Hansen, Villy Meldgaard, »Stoddere i virkeligheden«. Kristeligt Dagblad 13.3.1996. (Om G's kulturkamp efter 1832.)

Henriksen, Aage, »Digterne og det ubevidste«. Berlingske Tidende 1.3.1992. (Især om »Nordens Mytologi«).

Jensen, Søren E., »I salmen mødes jordisk og himmelsk« / »I salmen findes erindring og håb«. Kristeligt Dagblad 26. og 28.8.1996.

Knudsen, Tim, »Grundtvig eller grundlov«. Kristeligt Dagblad 1.6.1995.

Krogh, Kaj Ove, »Islam og Grundtvig«. Kristeligt Dagblad 12.9.91.

Kuhn, Hans, »Gegen schöne Schein und 'schwarze Schule'. Grundtvigs Kulturrevolution«. Neue Zürche Zeitung (Literaturbeilage) 5.-6.9.1992, s. 70. * 
Kvist, Morten, »Levende lærdom«. Politiken 7.11.1994. (Folkehøjskolen 150 år.)

Lomholt, Anders \& Lars Bøgeskov, »Splittelse blandt højskoler. Hvor er så denne Grundtvig?« / »Fra Grundtvig til Maharishi«. Politiken 20. og 21.7. 1996. (Debat: William Michelsen og Hanne Pjedsted, smst. 28.7.1996.)

Lundbye, Vagn, »Brev fra Grundtvig«. Politiken 22.7.1992. (Om danskhed og EU-folkeafstemningen 2.6.1992.)

Marfelt, Birgitte, »Grundtvig ind i norske hjerter«. Kristeligt Dagblad 22.6. 1993. (Samtale med Kirsti Aasen.)

Nägele, Horst, »Nærhedens realitet«. Kristeligt Dagblad 15.7.1992. (Om G og EU-folkeafstemningen.)

Rassadin, Stanislav, »Kan Grundtvig eksporteres til Rusland?« Weekendavisen 6.11.1992.

Ravn, Ib, »Det gode liv i de levendes land«. Berlingske Tidende 17.11.1996.

Rude, Eva, »Grundtvig i Afrika«. Berlingske Tidende 13.8.1994. (Om G-seminar i Ghana.)

Tandrup, Anders, »Filippinerne møder Grundtvig«. Kristeligt Dagblad 13.4. 1992. (Om befrielsesteologen Edicio de la Torres højskoleprojekt.)

Værge, Johannes, »lkke for at genere Kingo og Grundtvig«. Weekendavisen 21.5.1993. (Samtale med Sten Kaalø og Lisbeth Smedegaard Andersen.)

Winterø, Caja, »Kvinderne bag Grundtvig«. Berlingske Tidende 4.7.1993. (Om Lise Blicher, Marie Toft og Asta Krag-Juel-Vind-Frijs.)

Wissing, Lisbeth, »Grundtvig var lysår forud for Jung «. Information 17.1. 1992. (Samtale med Pia Skogemann.)

Yde, Henrik, »Nexø og Grundtvig«. Information 11.8.1992. 


\section{Varia}

Bertelsen, Otto, Dialogen mellem Grundtvig og Kierkegaard, 1990. (Anm.: Finn Hauberg Mortensen, Nordica, VIII, 1991, s. 320-27; > hans: Kierkegaard. På sporet af en ny udgave. I. 1993. S. 22-28.)

Brandt, Haakon, „En studietur om Grundtvig«. Dansk Kirketidende, CXLVIII, 1996, s. 201-02.

Christensen, Holger, »Blev Grundtvig myrdet?« Pinkerton, nr. 30, 1990, s. 20-23. (Om G's ældre bror Niels.)

Dansk ledelseskultur. Hvad har Grundtvig at sige den danske leder? 1996. 48 s. (1. udg., 1988, betitlet: Hvad [etc.]; på engelsk: The Cultural Basis of Danish Management: What Can the Manager Learn from Nicolai Frederik Severin Grundtvig?, 1995.) *

Falkenstjerne Dansk Litteratur. I: Fra Oldtiden til Aarestrup. Redigeret af Mogens Bjerring-Hansen, m.fl. 1990. S. 289-305.

Holbek, Bengt, »Grimm and [Svend] Grundtvig. A Footnote«. I: Leander Petzoldt \& Stefaan Top (red.), Dona Folcloristica. Festgabe für Lutz Röhrich zu seiner Emeritierung. Frankfurt a.M. [o.a.st.], 1990. S. 69-76. (Beiträge zur Europäischen Ethnologie und Folklore, Reihe A, 3.)

Høirup, Henning, »Uffe Hansen 14. december 1894 - 11. september 1994«. Grundtvig-Studier, 1995, s. 19-25.

Korsgaard, Ove, »Stiftelse af Grundtvig-Selskabet Japan [27.3.1994 i Fukuoka]«. Højskolebladet, 1994, s. 190-92.

Pedersen, Kim Arne, »Kaj Thaning in memoriam«. Grundtvig-Studier, 1994, s. 9-15.

Pedersen, Kim Arne, »Henning Høirup in memoriam«. Grundtvig-Studier, 1996, s. 11-24.

Riber-Jensen, Finn, »Grundtvig i USA«. Dansk Kirketidende, CXLVIII, 1996, s. 77-79.

Schjørring, Jens Holger, »Grundtvig - Danmark - Letland. Indtryk efter et besøg i Riga«. Århus Stift, XXX, 1992, s. 42-50. 
Schjørring, Jens Holger, Grundtvigs billedsprog - og den kirkelige anskuelse. 1990. (Anm.: Mogens Bjerring-Hansen, Grundtvig-Studier, 1992, s. 116-18.)

Thyssen, Anders Pontoppidan, Grundtvig og den grundtvigske arv. Afhandlinger. 1991. (Anm.: Stig G. Rasmussen, Prasteforeningens Blad, LXXXI, 1991, s. 741-44.)

Grundtvig-Studier, 1992. (Anm.: Jakob Fløe Nielsen, Dansk Kirketidende, CXLV, 1993, s. 153-55.)

Grundtvig-Studier, 1996. (Anm.: Jakob Fløe Nielsen, Prasteforeningens Blad, LXXXVII, 1997, s. 474-76.)

Grundtvig på norsk. Medlemsblad for Grundtvigselskapet, norsk avdeling. Juni 1996. $8 \mathrm{~s}$. 